\title{
Increasing Water Temperature in a Bio-Geyser during Ensiling of Berseem
}

\author{
InamH ${ }^{1 *}$, Ramzan $M^{1}$, HanifM${ }^{1}$, Khattak MK $^{1}$, Khan MT $^{2}$ \\ ${ }^{1}$ Department of Agricultural Mechanization, The University of Agriculture, Pakistan \\ ${ }^{2}$ Department of Animal Nutrition, The University of Agriculture, Pakistan \\ *Corresponding author: Inam H, Department of Agricultural Mechanization, Faculty of Crop Production, The University of Agriculture, Pakistan
}

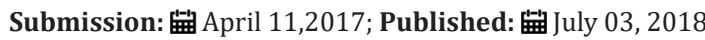

\begin{abstract}
A model silo cum bio geyser system was developed in The University of Agriculture Peshawar to utilize the biomass. In this silo, impact of biomass combination (Berseem and Mott grass) and fermenting agent (rumen liquor) on the amount of heat loss during ensiling. The experiments were laid out in completely randomized design having four treatments and three replications with twelve observations. In the silo water was stored in a Copper pipe located in the middle of the silo while silage was prepared around the pipe. During the fermentation process heat evolved was transferred to the pipe heating the water. Two biomass combination (Berseem only and Berseem 50\% + Mott grass 50\%) and two levels of fermenting agent (rumen liquor $1 \%$ and rumen liquor $0 \%$ as control) were used. Four treatments involved in this experiment were; 1 . Berseem + rumen liquor, 2 . Berseem + Mott grass + rumen liquor, 3. Berseem + control and 4. Berseem + Mott grass + control. Biomass combination and fermenting agent showed a significant effect on water temperature. It was also observed that the maximum temperature of water was recorded $48^{\circ} \mathrm{C}$ in treatment 4 while minimum temperatures of $43^{\circ} \mathrm{C}$ in treatment 3 and $39^{\circ} \mathrm{C}$ in treatment 1 respectively. It was concluded that the highest loss of heat during ensiling was obtained during the fermentation process of 5 days.
\end{abstract}

Keywords: Silage; Heat transfer; Warm water; Berseem; Rumen liquor

\section{Introduction}

World is currently facing energy crisis with a wide gap between supply and demand of electric power and natural gas. Power generation by old methods is either difficult, costly or need a long period of time for completion. Renewable energy sources like wind, solar, biogas and biomass offer sustainable solution. We can easily attain energy from biomass. Besides animal dung, agricultural wastes, weeds and fresh water algae make millions of kilogram of biomass on daily basis, which can easily be utilized to produce energy.

Energy is the backbone of industrialization and development of a country. Like environmental issue, there are many problems which show a relationship between supply and use of energy. The future of the country is dependent on high energy usage with minimum environmental effect. There is a close relationship among energy, environment and development. Although, some energy resources are responsible for environmental pollution but some resources may not result environmental changes and global warming are known as renewable energy or non conventional energy resources [1]. Non conventional energy resources that we get from natural resources like solar, wind; hydro, tidal and biomass are getting popular. Their utilization and marketing is increasing because they are low cost and ubiquitous [2].
Biomass is also a kind of renewable energies which can be used directly and indirectly. Direct use which is also called traditional use involves burning of wood or biomass for heating and cooking. While indirect use which is also called modern or commercial biomass use, involves advanced processes for production of energy sources like biodiesel, biogas and bio ethanol. Indirect use is commonly used in developing countries because they have technologies and the capability of cost involved. Biomass combustion provides $15 \%$ of the world energy demand. Above $70 \%$ of all biomass is used for domestic purposes, whereas $14 \%$ for commercial purpose and $11 \%$ for converting electricity, heat and $5 \%$ for preparing energy sources in the form of liquid(bio ethanol, bio diesel etc.), solid (pellet, silage and compost etc.) and gas (biogas) all around the world [3].

There are various processes which are followed for the conversion of biomass and residues to energy resource. Among these processes, the most environment friendly process is biological processes which use biological catalyst like rumen liquor, is typically discriminating and gives a tiny number of products in high quality [4]. In the biological process respiration which is a biochemical process occurs in all living things. Respiration has two types; aerobic and anaerobic respiration. Aerobic respiration 
produces more heat as compared to anaerobic respiration. Heat produced due to respiration of living things in damp environment is much higher than in dry environment. Microorganisms also increase the temperature of stored agriculture products.

Dairy farmers produce silage because of anaerobic respiration. The silage is consumed by dairy cattle and other ruminants as a part of their daily feeding program [5]. Ensilage is the process of biomass fermentation. It is typically prepared from grass crops including maize or other cereal crops using the entire green plant. Many field crops can be utilized for production of silage. Silage can be prepared either by introducing green vegetation in the silo or by piling it in a huge heap coated with plastic sheet which result loss of heat from vegetation [6].

Heat transfers from warmer to cooler object by conduction, convection or radiation process. Ideally, the heat loss from the warmer body and heat gain by the cooler object will be equal. The maximum heat transfer is dependent on the mass, specific heat and temperature difference of the body. In the warm body there must be a temperature gradient through which heat will be transfer from one part to another [7]

Fermentation or anaerobic respiration causes release of energy captured within the molecules in the form of carbohydrates and protein etc. when the bacteria or some other decomposing organisms make a symbiotic relationship with the biomass; enhance the fermentation as a result high energy may lose in the form of heat [8].

The purpose of study was to examine the effect of different biomass levels and fermenting agent on production and loss of heat from silage. The hypothesis of this study was the heat evolved from ensiling depends on type of biomass and fermenting agent.

\section{Materials and Methods}

\section{Research site}

The research was performed in the Department of Agricultural Mechanization, The University of Agriculture Peshawar Pakistan. The research period was 60 days and silo was filled after each 20 days.

\section{Development of a silo cum bio geyser}

Completely sealed and insulated Plastic containers, having volume of $0.05 \mathrm{~m}^{3}$ each, were used for developing a silo cum bio geyser. Within this container anaerobic respiration and anaerobic digestion took place. Heat evolved from the biomass was captured by water placed in the copper pipe in the centre of the container.

$$
\begin{aligned}
& \text { Diameter of pipe }(D)=0.0254 \mathrm{~m} \\
& \text { Height of pipe }(h)=0.5588 \mathrm{~m} \\
& \text { Volume of pipe }(V)=(\pi / 4) D^{2} h=0.011 \mathrm{~m}^{3}
\end{aligned}
$$

The insulation was made of polythene having insulation value of $0.3 \mathrm{~J} / \mathrm{m}^{2}$ with a thickness of $0.0127 \mathrm{~m}$.

\section{Experimental design and experimental layout}

In this study Completely Randomized Design (C.R.D) was used to determine the effect of various biomass combinations on loss of heat during ensiling. The first factor was the biomass in the form of combination of biomass in different percentages. The second factor was the addition of fermenting agent. The treatments and their combinations (layout) are as given below.

Biomass having two levels:

1. B1= Berseem only.

2. $\mathrm{B} 2=50 \%$ Berseem $+50 \%$ Mott grass.

Fermenting agents with two levels:

1. F1= addition of rumen liquor.

2. F2= Control

The following combinations of biomass levels and fermenting agent were used.

1. F1B1

2. F1B2

3. F2B1

4. $\quad$ F2B2

\section{Data Collection}

The data was collected on

1. Ambient Temperature $\left({ }^{\circ} \mathrm{C}\right)$

2. Water Temperature in water pipe $\left({ }^{\circ} \mathrm{C}\right)$

3. Biomass Temperature in digester $\left({ }^{\circ} \mathrm{C}\right)$

\section{Ambient temperature}

The temperatures outside from the silo were recorded by thermometer in degree Celsius with interval of 2 hours every day near the silo in shade.

\section{Water temperature in water pipe}

The temperature of water was recorded by the thermometer, placed in water pipe for about 2 minutes, in degree Celsius every day with interval of 2 hours. After taking temperature reading, the water pipe was covered and sealed with lid of plastic bottle.

\section{Biomass temperature in digester}

The Average temperature of biomass was also recorded by thermometers in different position within the silo.

\section{Statistical analysis}

Total of four treatments with three replications were used in Completely Randomized Design to check which treatment is efficient towards achieving warmest water in the bio geyser having highest digestibility. The treatment means were evaluated and contrasted by using least significant difference (LSD) test at 5\% level of probability [9]. 


\section{Results and Discussion}

The data collected during study period were analyzed and summarized below.

\section{Ambient temperature}

Highest ambient temperature $\left(20{ }^{\circ} \mathrm{C}\right)$ and lowest ambient temperature $\left(10^{\circ} \mathrm{C}\right)$ was recorded during research study. Ambient temperature showed highly significant effect on the biomass combination and fermenting agent. There was highest significance means difference between treatment F1B1 and F2B2. While the lowest significance means difference was observed between treatments F2B1 and F1B2 but in case of F1B2 all observations showed that there was rise in temperature within the digester because aerobic and anaerobic respiration took place in the digester. According to Ashbell et al. [10] ambient temperature had significant effect on silage preparation and its digestibility.

\section{Temperature of water and biomass:}

In this process the heat produced was utilized for heating of water. The heat gained up to the temperature of $45^{\circ} \mathrm{C}$. The Average highest water and biomass temperature in Berseem with rumen liquor shown in Figure 1 was $43{ }^{\circ} \mathrm{C}$ and $42{ }^{\circ} \mathrm{C}$ respectively. The lowest temperature of water and biomass was $25{ }^{\circ} \mathrm{C}$ and $28{ }^{\circ} \mathrm{C}$ respectively. The rise in temperature of water and biomass was about $60 \%$. Highest temperatures of $47^{\circ} \mathrm{C}$ and $48{ }^{\circ} \mathrm{C}$ for water and biomass were observed in Berseem with rumen liquor and Mott grass as shown in Figure 2. The rise in temperature in F1B2 was $90 \%$. Figure 3 show that the highest temperature of water and biomass were $39^{\circ} \mathrm{C}$ and $40{ }^{\circ} \mathrm{C}$ respectively in Berseem with control. Figure 4 shows that the highest temperature of water and biomass were $43{ }^{\circ} \mathrm{C}$ and $44{ }^{\circ} \mathrm{C}$ respectively in Berseem and Mott grass with control. The rise in temperature was above $60 \%$.

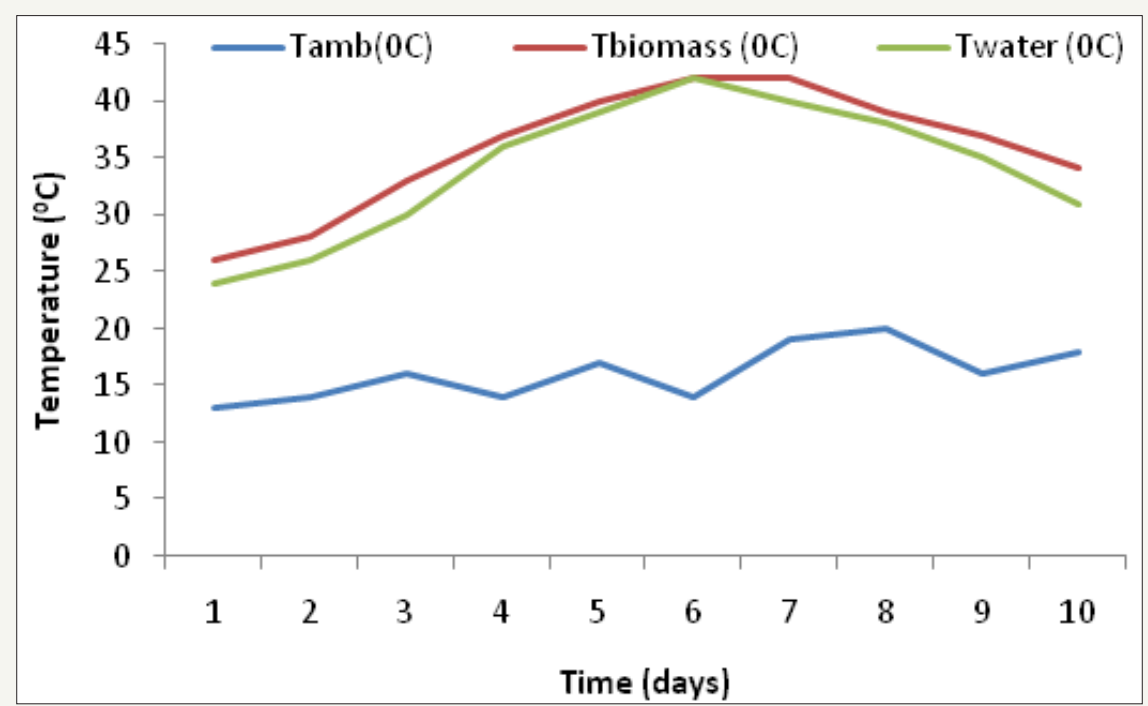

Figure 1: Average temperature of water, ambient and biomass (F1B1).

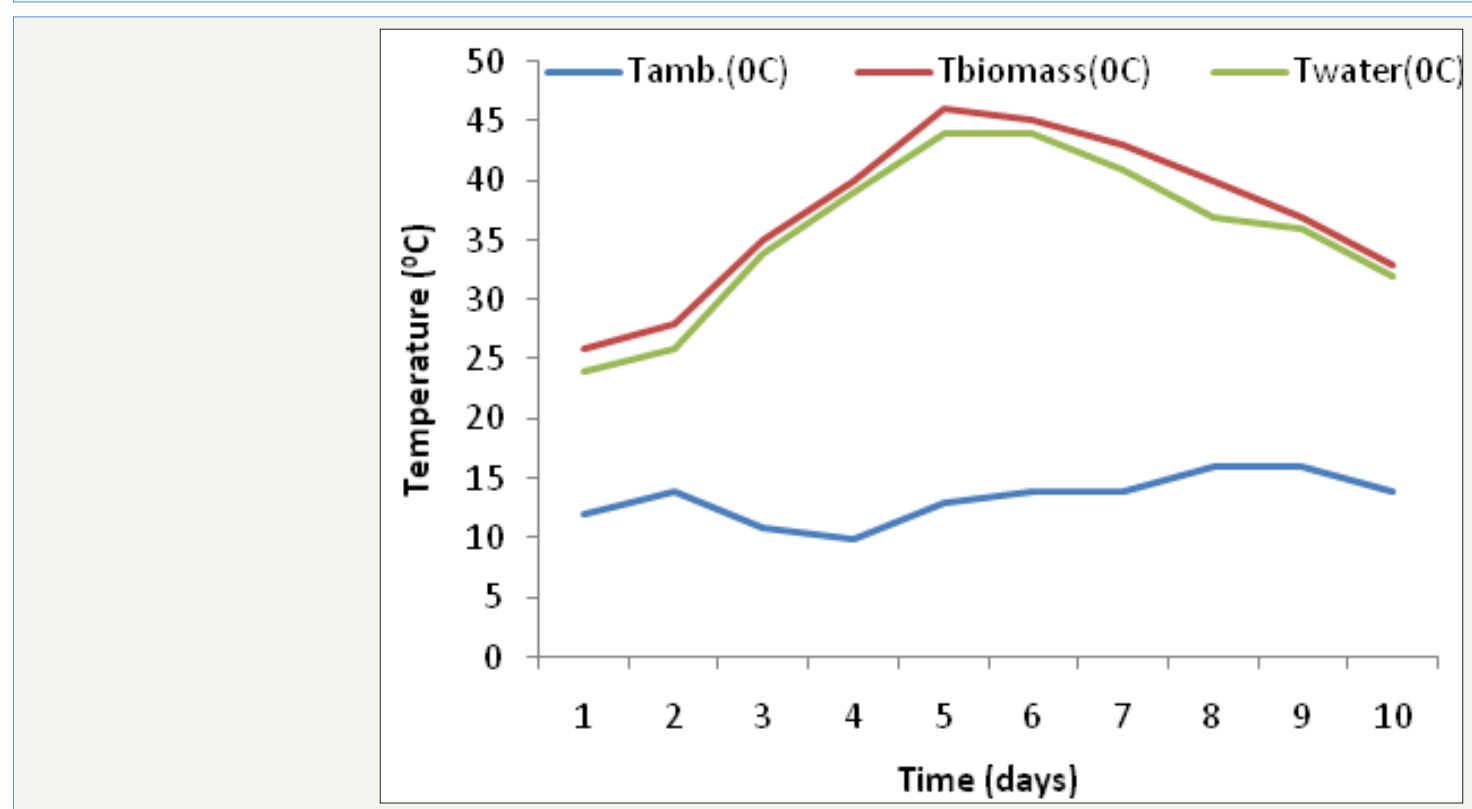

Figure 2: Average temperature of water, ambient and biomass (F1B2). 


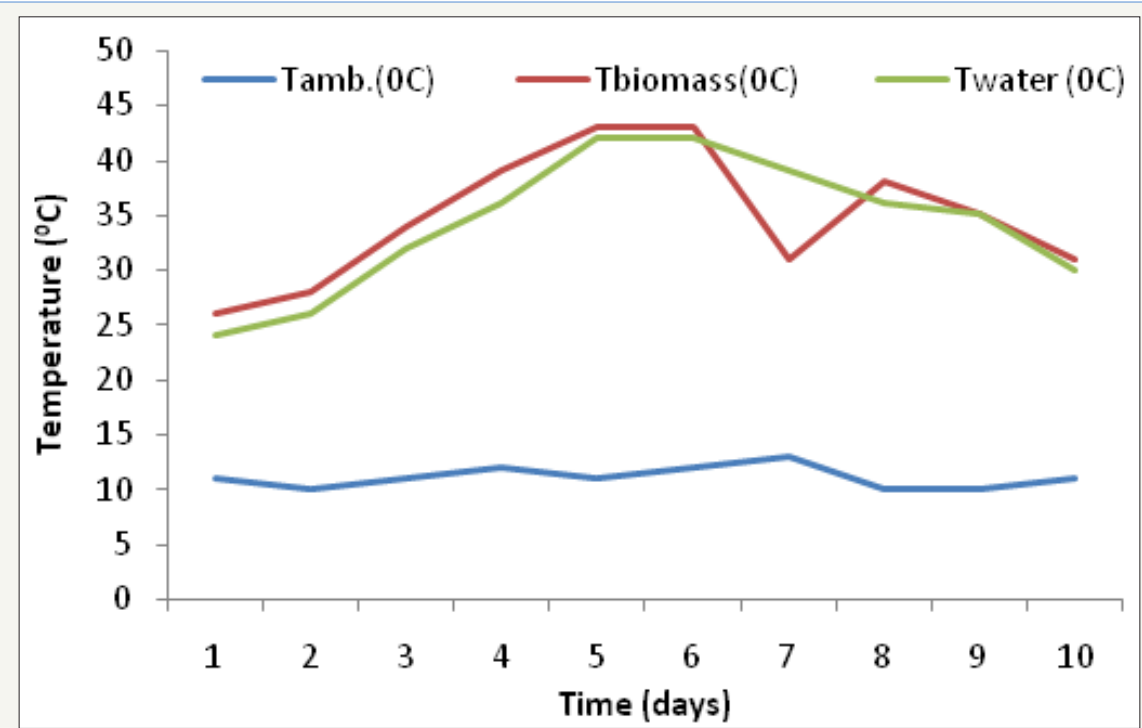

Figure 3: Average temperature of water, ambient and biomass (F2B1).

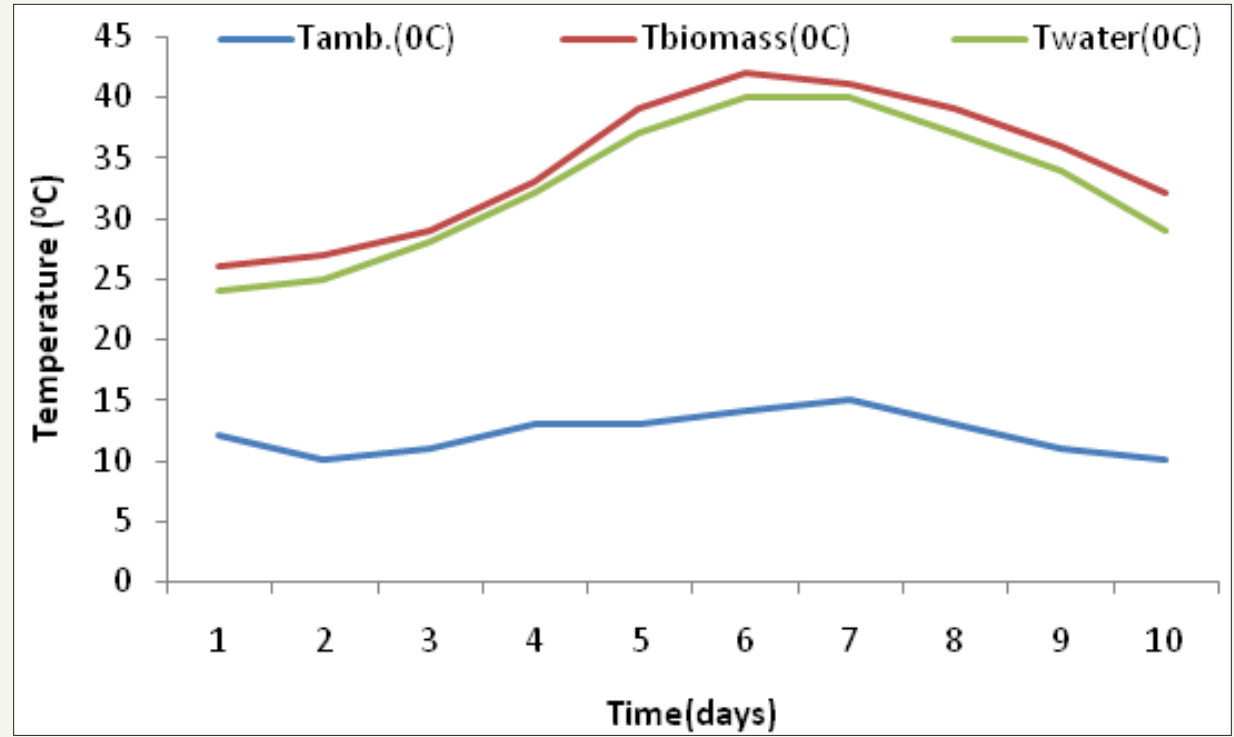

Figure 4: Average temperature of water, ambient and biomass (F2B2).

The temperature of water in F1B2 (berseem and Mott grass with rumen liquor) was significantly higher than that of F2B1 (Berseem with control). Huhtanen reported that the minimum aerobic temperature for corn silage in control was $95^{\circ} \mathrm{F}$. Temperature of silage was increased in the presence of air and fungi action which causing serious damage. Presence of air for long time in the silage results spoilage. Decrease in moisture content result decreased the specific heat of silage. Thus the heat produced in the silage increases the temperature of dried silage [11].

In aerobic decomposition of agricultural wastes, a sizeable heat is generated which can reached as high as $90{ }^{\circ} \mathrm{C}$ within $4-5$ days. This heat was utilized for heating of water and such type of energy free facility by the microbial degradation of agricultural waste [12]. Aerobic respiration results in the loss of dry matter, energy and carbohydrates which begins from harvesting of crop till providing anaerobic condition or sealing. This aerobic respiration causes loss in the energy and carbohydrates in the first 4-5 days of ensiling after which fermentation starts and carbohydrates change into lactic acid. If the respiration is permitted to carry on for an extended time, ( 5 days onward) there will be a huge amount of heat created which smash up protein and decrease digestibility [8].

During ensiling and sealing some of the oxygen molecules are remained in the container which is sufficient for starting aerobic respiration. After one and a half hour of sealing the increase in temperature of the biomass (Berseem silage) was $2{ }^{\circ} \mathrm{C}$ while in case of Berseem + Mott Grass Silage the temperature increased up to $3{ }^{\circ} \mathrm{C}$ because of the presence of Dry Matter. After the first day of ensiling, the temperature of biomass increased drastically. The results showed that the heat produced in aerobic respiration during 4-5 days of ensiling is higher in the Berseem only Silage than that of Berseem + Mott Grass Silage. In case of Berseem Silage, the average temperature of water within the pipe increased from $24{ }^{\circ} \mathrm{C}$ to 43 ${ }^{\circ} \mathrm{C}$. After 5 days the aerobic respiration stopped and fermentation starts as a result the temperature of water once again drops from 
$45{ }^{\circ} \mathrm{C}$ gradually and reached $30{ }^{\circ} \mathrm{C}$. On the other hand, in case of Berseem + Mott Grass Silage, the average temperature of water increased from $24{ }^{\circ} \mathrm{C}$ to $47^{\circ} \mathrm{C}$ and then decreased to $34^{\circ} \mathrm{C}$ because of the presence of higher amount of Dry Matter in the Berseem + Mott Grass Silage than that of Berseem only Silage [13].

Analysis of variance showed that there was non-significant effect of biomass temperature on biomass combination and fermenting agent. Mean differences between all the treatments were very low which showed its non-significances but the temperature of biomass in F1B2 was much higher than the other three treatments. While water temperature showed significant effect on the combination of biomass and fermenting agent. The analysis showed that the increase in temperature of water in F1B2 is significantly higher than F2B1. So the highest mean differences were found between F1B2 and F2B1 while the lowest mean differences were recorded between the treatments F1B1 and F2B2 [14].

\section{Conclusion}

Data were recorded for the ambient temperature, biomass temperature in the silo, and temperature of water in the water pipe in degree Celsius. In case of ambient temperature, the highest recorded temperature was $20^{\circ} \mathrm{C}$ while the lowest temperature was $10^{\circ} \mathrm{C}$. There was a random increase or decrease in the ambient temperature and the effect of biomass combination and fermenting agent on ambient temperature was found significant [15].

In case of biomass temperature in the silo cum bio geyser, the highest average temperature $\left(47.10{ }^{\circ} \mathrm{C}\right)$ of biomass was found in the combination of Berseem, Mott grass and rumen liquor while the lowest average temperature $\left(34.7^{\circ} \mathrm{C}\right)$ of biomass was found in the treatment having Berseem with no fermenting agent. The effect of biomass combination and fermenting agent on the biomass temperature was found non-significant.

Highest average temperature of water in the water pipe in the middle of silo cum bio geyser was recorded as $46.5^{\circ} \mathrm{C}$ in the Berseem, Mott grass and rumen liquor while the lowest temperature of water in the water pipe was recorded as $32.9^{\circ} \mathrm{C}$ in case of Berseem in the absence of rumen liquor. The treatment consist of Berseem, Mott grass and rumen liquor and another treatment having Berseem with no rumen liquor showed significant effect on the temperature of water in the water pipe [16].

The result obtained from the experiment showed that the combination of Berseem, Mott grass and rumen produce warmest water $48^{\circ} \mathrm{C}$ at $4^{\text {th }}$ day of ensiling while the lowest temperature of water $\left(42{ }^{\circ} \mathrm{C}\right)$ was found in Berseem silage both in control and addition of rumen liquor. The biomass temperature above $50{ }^{\circ} \mathrm{C}$ results in high nutrients loss $[17,18]$. The biomass combination and fermenting agent significantly affected the temperature of water in the water pipe within the silo cum bio geyser. Time for heating of water in the water pipe within the silo depend upon specific heat and mass of biomass. As the biomass increases the time for heating of water decreases at constant volume of water. In this experiment, hot water achieved at fourth day of ensiling.

\section{References}

1. Dincer I, Rosen MA (1998) A worldwide perspective on energy, environment and sustainable development. Int J Energy Res 22(15): 1305-1321.

2. Sidhu KS (2005) Non-conventional energy resources. Director/ research Punjab state electricity board, PEC campus, Chandigarh, India, p: 10.

3. Anniehii (2011) Anti Essays.

4. Anthony BV (2012) Review of fast pyrolysis of biomass and product upgrading. J biomass and bioenergy 38: 68-94.

5. Ulysses AA, Maxon RC, Khan SH (1992) Handling, Management and Marketing of cereal grains. Food and Feed Grains Institute Manhattan, Kansas, USA.

6. George JR (1994) Extension Publications: Forage and Grain Crops. Iowa: Kendall, Hunt, Dubuque, USA, p: 152.

7. Donatello A (2011) Transient Heat Transfer. Springer Briefs in Applied Sciences and Technology, Publisher Springer Berlin Heidelberg, Germany.

8. Piltz JW, Kaiser AG (2002) Successful silage top fodder-1.

9. Steel RGD, Torrie HJ (1980) Principles and Procedures of statistics. Mc Graw Hill Book Co, New York, USA.

10. Ashbell G, Weinberg ZJ, Hen Y, Filya I (2002) The effects of temperature on the aerobic stability of wheat and corn silages. I Indus Microbiology and biotech 28(5): 261-263.

11. Stevenson KR, Gallagher DW (1976) Heat damage in hay crop silage. Ministry of Agriculture and food. Order no. 76-007.

12. Haider K, Ali Z, Azam F, Ali M (2013) Rapid agro-waste composting with bio geyser as a by-product. International Journal of Agricultural Sciences 3(3): 439-444.

13. Bilal MA (2008) Feeding value of Mott grass and its silage in lactating Sahiwal cows. Pak J Agri Sci 45(2).

14. Bolsen KK, Ashbell G, Weinberg ZG (1996) Silage fermentation and silage additives: Review. Asian-Aust J Anim Sci 9(5): 483-489.

15. Huhtanen P (1998) Supply of nutrients and productive responses in dairy cows given diets based on restrictively fermented silage. AGRIS 7 (2): 219-250.

16. Robert JVS (2002) Extension Veterinarian Troubleshooting Silage Problems: How to Identify Potential Problems. Department of Veterinary Science Penn State University, Pennsylvania, USA

17. Touqir NA, Khan MA, Sarwar M, Nisa M, Lee WS, et al. (2007) Influence of Varying Dry Matter and Molasses Levels on Berseem and Lucerne Silage Characteristics and Their In situ Digestion Kinetics in Nili Buffalo Bulls. Asian-Aust J Anim Sci 20(6): 887-893.

18. Wood Brian JB (1998) Microbiology of fermented foods. Springer, 1 \& 2: $p: 73$. 
Creative Commons Attribution 4.0 International License

For possible submissions Click Here

Submit Article

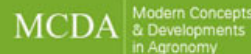

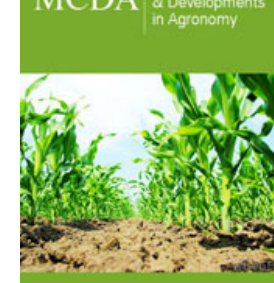

Modern Concepts \& Developments in Agronomy

\section{Benefits of Publishing with us}

- High-level peer review and editorial services

- Freely accessible online immediately upon publication

- Authors retain the copyright to their work

- Licensing it under a Creative Commons license

- Visibility through different online platforms 